\title{
Recent advances in studies on biochemical and structural properties of equilibrative and concentrative nucleoside transporters
}

\author{
Marzena Podgorska ${ }^{\bowtie}$, Katarzyna Kocbuch and Tadeusz Pawelczyk \\ Department of Molecular Medicine, Medical University of Gdansk, Gdańsk, Poland; \\ 凶e-mail: mpodgor@amg.gda.pl
}

Received: 16 May, 2005; revised: 4 August, 2005; accepted: 22 August, 2005

available on-line: 25 October, 2005

\begin{abstract}
Nucleoside transporters (NT) facilitate the movement of nucleosides and nucleobases across cell membranes. NT-mediated transport is vital for the synthesis of nucleic acids in cells that lack de novo purine synthesis. Some nucleosides display biological activity and act as signalling molecules. For example, adenosine exerts a potent action on many physiological processes including vasodilatation, hormone and neurotransmitter release, platelet aggregation, and lipolysis. Therefore, carrier-mediated transport of this nucleoside plays an important role in modulating cell function, because the efficiency of the transport processes determines adenosine availability to its receptors or to metabolizing enzymes. Nucleoside transporters are also key elements in anticancer and antiviral therapy with the use of nucleoside analogues. Mammalian cells possess two major nucleoside transporter families: equilibrative (ENT) and concentrative (CNT) $\mathrm{Na}^{+}$-dependent ones. This review characterizes gene loci, substrate specificity, tissue distribution, membrane topology and structure of ENT and CNT proteins. Regulation of nucleoside transporters by various factors is also presented.
\end{abstract}

Keywords: nucleoside transporters, gene locus, tissue distribution, substrate specificity, structure, adenosine

Nucleosides and nucleobases play important functions in the physiology of several organs. Adenosine, an endogenous nucleoside, regulates, among other processes, blood flow, myocardial slow action potentials, lymphocyte function, glucose metabolism, and neurotransmission (Mubagwa \& Flameng, 2001; Dunwiddie \& Masino, 2001; Ackley et al., 2003; Rosales et al., 2004). Therefore, processes that modify adenosine concentration may alter its action on several tissues.

The effect of adenosine is mediated by specific cell-surface receptors A1, A2a, A2b and A3 (Olah $\&$ Stiles, 2000). The affinity of these receptors for adenosine varies. Thus their activation depends on adenosine concentration. Metabolism and transport across the plasma membrane are the main factors influencing the adenosine level. Most nucleosides and their analogues such as anticancer and antiviral nucleoside drugs are hydrophilic molecules and require specific transport proteins to be transported in and out of the cell. Two major classes of nucleoside transport systems have been described in mammalian cells, the equilibrative transport system and the concentrative one (Baldwin et al., 2004; Gray et al., 2004; Kong et al., 2004). Nucleosides, nucleobases and their analogues are also substrates for other car-

Abbreviations: ara-A, adenine 9- $\beta$-D-arabinofuranoside (vidarabine); ara-C, cytosine $1-\beta$-D-arabinofuranoside (cytarabine); AZT, 3'-azido-3'-deoxythymidine (zidovudine); CdA, 2-chloro-2'-deoxyadenosine (cladribine); cib, concentrative nucleoside transport insensitive to NBTI accepting a broad range of permeants; cif, purine-preferring concentrative nucleoside transport insensitive to NBTI accepting formicin B as a permeant; cit, pyrimidine-preferring concentrative nucleoside transport insensitive to NBTI accepting thymidine as a permeant; $c s$, concentrative nucleoside transport sensitive to NBTI; csg, concentrative nucleoside transport sensitive to NBTI accepting guanosine; CNT, concentrative nucleoside transporter; ddA, 2', 3'-dideoxyadenosine; ddC, 2',3'-dideoxycytidine (zalcitabine); ddI, 2',3'-dideoxyinosine (didanosine); dFdC, 2' ,2'-difluorodeoxycytidine (gemcitabine); ei, equilibrative nucleoside transport insensitive to inhibition by NBTI; ENT, equilibrative nucleoside transporter; es, equilibrative nucleoside transport sensitive to inhibition by NBTI; FdU, 5-fluoro-2'-deoxyuridine; h, human; IdU, 5-iodo-2'-deoxyuridine; IFN- $\gamma$, interferon- $\gamma$; LPS, lipopolysaccharide; $\mathrm{m}$, murine; M-CSF, macrophagecolony stimulating factor; NBTI, nitrobenzylthioinosine; NT, nucleoside transporters; PI3K, phosphatidylinositol 3-kinase; PKC, protein kinase C; PMA, phorbol 12-myristate 13-acetate; r, rat; T3, triiodo-L-thyronine; TM, transmembrane; TNF- $\alpha$, tumor necrosis factor $\alpha$. 
rier proteins such as organic anion and cation transporters and $\mathrm{ABC}$ transporter proteins that mostly function as efflux transporters (Pastor-Anglada et al., 2005). In our review we focus on equilibrative (ENT) and concentrative (CNT) nucleoside transporters.

The equilibrative transport system mediates nucleoside transport in both directions depending on the nucleoside concentration gradient across the plasma membrane (Fig. 1). This class of nucleoside transport system is subdivided in two types (es and ei) based on their sensitivity to nitrobenzylthioinosine (NBTI). The es transport system is highly sensitive to inhibition by NBTI $\left(K_{\mathrm{i}}=0.1\right.$ to $\left.10 \mathrm{nM}\right)$. In contrast, the ei transport system is resistant to NBTI up to $1 \mu \mathrm{M}$ (Griffith \& Jarvis, 1996; Kiss et al., 2000; Leung et al., 2001). Currently four transporters (ENT1, ENT2, ENT3 and ENT4) belonging to the equilibrative transport system have been identified and cloned (Table 1). ENT1 and ENT3 are susceptible to NBTI, whereas this compound does not inhibit ENT2. ENT4 has been identified only recently and its transporting characteristics have not been fully determined. These four members of the equilibrative transport system are widely distributed among various cell types, but the number of molecules of each nucleoside transporter depends on the cell and tissue type. All transporters are able to transport adenosine, but they have different capacities to transport other nucleosides and nucleobases (Baldwin et al., 2004; Kong et al., 2004).

The concentrative transport system is $\mathrm{Na}^{+}$ dependent and the movement of the nucleoside regardless of its concentration gradient is coupled to that of the sodium ion (Fig. 1). Six functionally different concentrative nucleoside transport activities have been described in human cells and they have been named in two different ways (Table 1). The first nomenclature is numerical and follows the order of

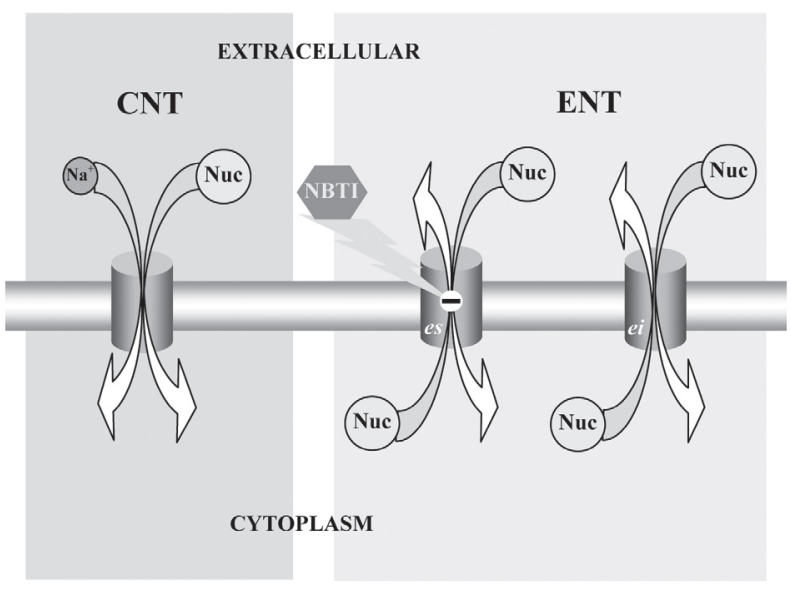

Figure 1. A model of nucleoside flux mediated by $\mathrm{Na}^{+}-$ dependent nucleoside transporters (CNT) and equilibrative nucleoside transporters (ENT).

Nuc, nucleoside, NBTI, nitrobenzylthioinosine. discovery (N1-N6), and the second one is based on the substrate specificity (cit, cif, cib, cit-like, cs, csg). The N1-cif activity is purine-selective, the N2-cit transport system accepts pyrimidine nucleosides, the N3-cib system transports both purine and pyrimidine nucleosides, the N4-cit-like system is selective for pyrimidine nucleosides but also accepts adenosine and guanosine, the N5-cs system transports adenosine and its analogues, and the N6-csg activity is guanosine-selective (Thorn \& Jarvis, 1996; Flanagan \& Meckling-Gill, 1997; Cass et al., 1998; Baldwin et al., 1999; Cabrita et al., 2002). To date three different proteins responsible for the cit (CNT1), cif (CNT2), and $c i b$ (CNT3) activities have been identified (Gray et al., 2004; Kong et al., 2004). Proteins that demonstrate the N4-cit-like, N5-cs or N6-csg activities have not been identified yet.

\section{THE EQUILIBRATIVE NUCLEOSIDE TRANSPORTERS FAMILY}

\section{ENT1}

The human gene encoding the hENT1 protein has been localized to region p21.1-21.2 on chromosome 6 (Baldwin et al., 2004). The mRNA for hENT1 is widely distributed in different tissues, including erythrocytes, liver, heart, spleen, kidney, lung, intestine, and brain (Table 2) (Griffith \& Jarvis, 1996; Lum et al., 2000; Pennycooke et al., 2001).

Human ENT1 protein consists of 456 amino acids and its sequence displays about $78 \%$ identity to the rat (rENT1) and mouse (mENT1) homologues. Splice variants of ENT1 have been found only in the mouse. The mRNA for the shorter form of mENT1 termed mENT1.2 (458 aa) is produced by alternative splicing at the end of exon 7. Mouse ENT1.2 protein was shown to be commonly co-expressed with mENT1.1 (460 aa) and the highest level was found in the liver, heart and testis (Handa et al., 2001). The two forms of mENT1 protein appear to be functionally identical, although mENT1.2 lacks the potential casein kinase II phosphorylation site.

Both rat and human ENT1 proteins display broad substrate specificity for pyrimidine and purine nucleosides, but are unable to transport the pyrimidine base uracil (Yao et al., 1997). Human ENT1 has been reported to transport the nucleoside analogues used in the treatment of cancers, including $\mathrm{CdA}$ and ara-C. On the other hand, hENT1 only weakly transports the antiviral nucleoside analogues such as ddC and does not accept AZT (Griffiths et al., 1997; Mackey et al., 1998). Among the ENT1 proteins expressed in various species there are some differences in susceptibility to inhibition by specific compounds. Human ENT1, which is sensitive to NBTI, is also in- 
Table 1. Nucleoside transport systems and their specificity

\begin{tabular}{|c|c|c|}
\hline Nucleoside transport system & Protein & Substrate selectivity \\
\hline es (equilibrative, sensitive to NBTI) & ENT1 & purine and pyrimidine nucleosides \\
\hline$e i$ (equilibrative, insensitive to NBTI) & ENT2 & purine and pyrimidine nucleosides and some nucleobases \\
\hline es (equilibrative, sensitive to NBTI) & ENT3 & purine and pyrimidine nucleosides and nucleobases \\
\hline (equilibrative) & ENT4 & adenosine \\
\hline $\begin{array}{l}\text { N1/cif } \\
\text { (concentrative, insensitive to NBTI) }\end{array}$ & CNT2 (SPNT) & purine nucleosides, uridine, formycin B \\
\hline $\begin{array}{l}\mathbf{N} 2 / \text { cit } \\
\text { (concentrative, insensitive to NBTI) }\end{array}$ & CNT1 & pyrimidine nucleosides, adenosine \\
\hline $\begin{array}{l}\mathrm{N} 3 / \mathrm{cib} \\
\text { (concentrative, insensitive to NBTI) }\end{array}$ & CNT3 & purine and pyrimidine nucleosides \\
\hline $\begin{array}{l}\text { N4/cit-like } \\
\text { (concentrative) }\end{array}$ & unknown & pyrimidine nucleosides, adenosine and guanosine \\
\hline $\begin{array}{l}\mathrm{N} 5 / \text { cs } \\
\text { (concentrative, sensitive to NBTI) }\end{array}$ & unknown & adenosine analogues (formycin B, fludarabine, cladribine) \\
\hline $\begin{array}{l}\mathrm{N} 6 / c s g \\
\text { (concentrative, sensitive to NBTI) }\end{array}$ & unknown & guanosine \\
\hline
\end{tabular}

hibited by the coronary vasodilators dipyridamole, dilazep, and draflazine. In contrast, rat ENT1 that is also inhibited by NBTI appears to be resistant to those compounds (Yao et al., 1997; Sundaram et al., 1998; Kiss et al., 2000; Ward et al., 2000; Baldwin et al., 2004).

\section{ENT2}

Human ENT2 (hENT2) protein that is responsible for the $e i$ type nucleoside transport is encoded by a gene localized at position $13 \mathrm{q}$ on chromosome 11 (Table 2). The mRNA for ENT2 was reported to be present in several tissues including heart, kidney, brain, placenta, thymus, pancreas, intestine, and prostate, but the highest expression level was observed in skeletal muscle (Griffiths et al., 1997; Crawford et al., 1998; Lum et al., 2000; Pennycooke et al., 2001).

Human ENT2 consists of 456 amino acids and their sequence displays $88 \%$ identity to mouse (mENT2) and rat (rENT2) homologues. In human, beside the 456-amino acid ENT2 protein, there exist at least two shorter forms of ENT2 generated from mRNA splice variants. The 326 aa protein termed
hHNP36 lacks the first three transmembrane domains and is inactive as a nucleoside transporter. Inactive is also the second splice variant, a 301-amino acid protein named hENT2A that lacks the C-terminal domain (Crawford et al., 1998).

The ENT2 protein accepts a broad range of substrates, including purine and pyrimidine nucleosides and nucleobases. It has been postulated that human ENT2 plays a role in the efflux and reuptake of inosine and hypoxanthine generated from adenosine during and after strenuous physical exercise (Griffiths et al., 1997). ENT2 (both rat and human) is much less susceptible to inhibition by NBTI and the coronary vasodilators dipyridamole and draflazine than ENT1 (Yao et al., 1997; Sundaram et al., 1998; Ward et al., 2000; Baldwin et al., 2004). In contrast to hENT1 protein, hENT2 can transport the antiviral nucleoside analogue AZT and exhibits a greater affinity for ddC (Griffiths et al., 1997; Crawford et al., 1998; Yao et al., 2001).

\section{ENT3}

The gene encoding the human ENT3 (hENT3) protein is located at position q22.1 on chromosome

Table 2. Characteristics of human nucleoside transporters

\begin{tabular}{|c|c|c|c|}
\hline $\begin{array}{l}\text { Name of gene/ } \\
\text { protein }\end{array}$ & $\begin{array}{l}\text { Chromosomal } \\
\text { location of gene }\end{array}$ & $\begin{array}{l}\text { Amino-acid } \\
\text { residues }\end{array}$ & Tissue distribution \\
\hline SLC29A1/hENT1 & $6 p 21.1-$ p21.2 & 465 & $\begin{array}{l}\text { ubiquitous, placenta, liver, heart, spleen, kidney, lung, colon and } \\
\text { brain }\end{array}$ \\
\hline SLC29A2/hENT2 & $11 q 13$ & 465 & ubiquitous, predominantly abundant in skeletal muscle \\
\hline SLC29A3/hENT3 & $10 \mathrm{q} 22.1$ & 475 & ubiquitous, intracellular membranes \\
\hline SLC29A4/hENT4 & $7 \mathrm{p} 22.1$ & 530 & ubiquitous \\
\hline SLC28A1/hCNT1 & $15 q 25-q 26$ & 650 & jejunum, kidney, liver, small intestine, brain \\
\hline SLC28A2/hCNT2 & $15 q 15$ & 658 & $\begin{array}{l}\text { kidney, liver, small intestine, jejunum, colon, rectum, heart, brain, } \\
\text { placenta, pancreas, spleen, skeletal muscle }\end{array}$ \\
\hline SLC28A3/hCNT3 & $9 q 22.2$ & 691 & $\begin{array}{l}\text { bone marrow, pancreas, trachea, mammary gland, placenta, intestine, } \\
\text { lung, kidney, liver, prostate, testis }\end{array}$ \\
\hline
\end{tabular}


10 (Table 2). The mRNA for ENT3 has been detected in a variety of mouse and human tissues, including brain, kidney, colon, testis, liver, spleen, placenta (highest level), and in a number of neoplastic tissues (Hyde et al., 2001; Baldwin et al., 2004; 2005). Human ENT3 is a 475-residue protein displaying $73 \%$ identity to the mouse homologue (mENT3) (Baldwin et al., 2004; 2005; Kong et al., 2004). ENT3 has a characteristic, long (51 aa) hydrophilic N-terminal region preceding the first transmembrane (TM1) domain. The N-terminal region of ENT3 consists of two dileucine motifs characteristic for endosomal, lysosomal targeting motifs. This architectural design distinguishes the ENT3 protein from other members of the equilibrative transporters family. Indeed, it was demonstrated that hENT3 protein is predominantly localized intracellularly and that mutation of the dileucine motif to alanine triggers the relocation of ENT3 protein to the cell surface (Baldwin et al., 2004; 2005).

In comparison with ENT1, the ENT3 protein is much less susceptible to inhibition by NBTI and coronary vasodilatory drugs like dipyridamole and dilazep. Human ENT3 demonstrates a broad selectivity for nucleosides, but does not transport hypoxanthine. The hENT3 protein facilitates transport of several adenosine analogues like $\mathrm{CdA}$ and cordycepin (3'-deoxyadenosine). The antiviral purine and pyrimidine nucleoside analogues ddI, ddC and in particular AZT are efficiently transported by this protein (Baldwin et al., 2004; 2005).

\section{ENT4}

The gene encoding the human ENT4 protein is located on chromosome 7 at position p22.1. The mRNA for hENT4 was detected in several human tissues (Table 2). Human ENT4 is a 530 -residue protein displaying $86 \%$ identity to its 528-residue mouse homologue (Baldwin et al., 2004). The substrate specificity of hENT4 has not been determined in detail, but among the ENT proteins hENT4 has the lowest affinity for adenosine (Kong et al., 2004).

\section{THE CONCENTRATIVE NUCLEOSIDE TRANSPORTERS FAMILY}

\section{CNT1}

The mRNA for rCNT1 was detected in several tissues including jejunum, kidney, liver, small intestine, and in many regions of the brain (Huang et al., 1993; Anderson et al., 1996; Pennycooke et al., 2001). The gene encoding human CNT1 protein is located at position q25-26 on chromosome 15 (Table 2). Human CNT1 is a 650 -amino acid protein displaying
$83 \%$ identity to its rat 648-residue homologue (Ritzel et al., 1997). Rat CNT1 protein appears to be a typical cit type transporter (N2 subtype) dependent upon sodium and preferentially transporting pyrimidine nucleosides (Huang et al., 1994; Ritzel et al., 1997; Wang et al., 1997). This protein also binds adenosine, but this purine is weakly transported. Rat CNT1 transports several antiviral nucleoside analogues, including AZT and ddC. Nucleoside analogues such as ara-C and $\mathrm{dFdC}$ that are used in anticancer therapy are also substrates for hCNT1 (Yao et al., 1997).

\section{CNT2}

The protein responsible for the cif type process (N1) that was identified by molecular cloning in the rat liver was named sodium-dependent purine nucleoside transporter (SPNT). The concentrative transporter cloned later from rat intestine was called rCNT2 (Huang et al., 1993; Wang et al., 1997). These two transporters are almost identical proteins that differ in a conservative substitution of glycine for alanine and valine for isoleucine at positions 419 and 522, respectively (Che et al., 1995; Yao et al., 1997; Cass et al., 1998).

The gene encoding human CNT2 (hCNT2) protein is located at position q15 on chromosome 15 (Table 2) (Ritzel et al., 1998). The mRNA for hCNT2 has been detected in a wide range of tissues including liver, kidney, jejunum, spleen, heart, brain, placenta, pancreas, colon, rectum, small intestine and skeletal muscle (Che et al., 1995; Wang et al., 1997; Pennycooke et al., 2001).

Human and rat CNT2 proteins are $81 \%$ identical in respect to amino-acid sequences, but have different substrate specificities and regulation (Che et al., 1995; Wang et al., 1997). Both, rat and human CNT2 proteins transport purine nucleosides, including formycin B and uridine (Che et al., 1995; Wang \& Giacomini, 1997). Human CNT2 has also been reported to facilitate the uptake of antiviral compounds such as ddI and ribavirin (1- $\beta$-D-ribofuranosyl-1,2,4triazole-3-carboxamide) used in the treatment of patients with HIV and hepatitis C, respectively (Ritzel et al., 1997; Gerstin et al., 2002). However, hCNT2 does not transport the antiviral drugs like ddA, araA, FdU and IdU (Patil et al., 1998; Ritzel et al., 1998; Gerstin et al., 2002).

\section{CNT3}

The gene for human CNT3 protein is located on chromosome 9 at position q22. The mRNA for hCNT3 has been detected in pancreas, trachea, bone marrow, and mammary gland (Table 2). This protein exhibits a cib activity (N3 subtype) and transports both purine and pyrimidine nucleosides in a sodium 
A

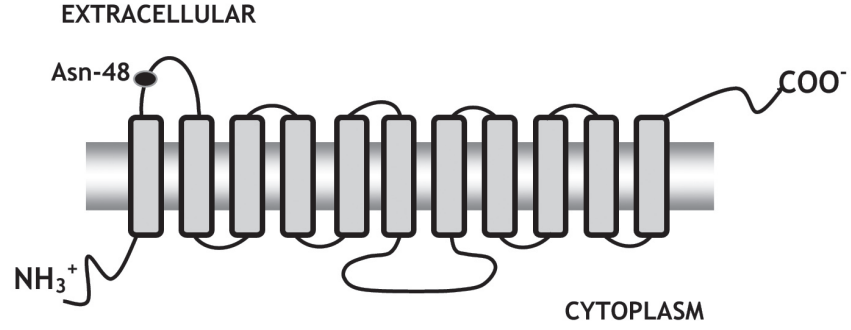

B

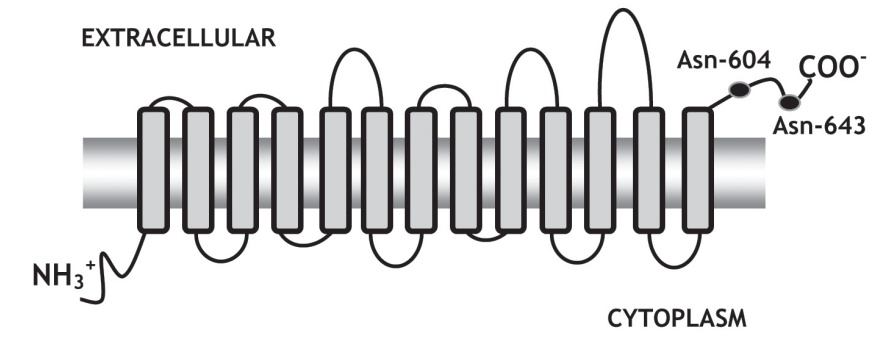

\author{
Figure 2. Topology of hENT1 (A) and \\ hCNT1 (B). \\ Grey rectangles indicate transmembrane \\ $\alpha$-helices. Black circles indicate glycosyl- \\ ation sites in hENT1 (Vickers et al., 1999) \\ and hCNT1 (Loewen et al., 1999).
}

dependent manner (Ritzel et al., 2001). The hCNT3 protein exhibits a 2:1 stoichiometry for cotransport of $\mathrm{Na}^{+}$and nucleoside (Ritzel et al., 2001) in contrast to the 1:1 ratio employed by CNT1 and CNT2 (Plagemann \& Aran, 1990). The CNT3 protein facilitates transport of several purine and pyrimidine analogues such as $\mathrm{CdA}, \mathrm{dFdC}$ and FdU that are used in anticancer therapy (Ritzel et al., 2001; Zhang et al., 2003; Badagnani et al., 2005).

\section{TOPOLOGY AND FUNCTION OF THE ENT AND CNT PROTEINS}

Each member of the ENT family consists of 11 hydrophobic transmembrane (TM) $\alpha$-helices arranged in the plasma membrane by such way that the $\mathrm{N}$-terminus is cytoplasmic while the C-terminus is located in the extracellular space (Sundaram et al., 2001a). These transporters are posttranslationally modified by glycosylation. The sites of glycosylation in hENT1 and hENT2 are located in the large extracellular loop between TM helices 1 and 2 (Fig. 2). Human ENT1 contains one such site, whereas hENT2 has two (Griffiths et al., 1997; Vickers et al., 1999; Sundaram et al., 2001a). Experiments with cells grown in a medium containing a drug that prevents glycosylation (tunicamycin) showed that glycosylation of the ENT1 protein is not essential for its es activity (Hogue et al., 1990). However, a study on a glycosylation-defective mutant of hENT1 has demonstrated that glycosylation of hENT1 modulates its sensitivity to inhibition by NBTI and coronary vasodilators dipyridamole and dilazep (Vickers et al., 1999). In contrast, N-glycosylation of hENT2 has no effect on its nucleoside transport kinetics, but is required for efficient targeting of this carrier protein to the plasma membrane (Ward et al., 2003). Human and mouse ENT3 are also glycosylated within the 12 TM loop, whereas the exact location of the glyco- sylation site in the C-terminal tail of ENT4 remains unknown. Another feature of the mammalian ENT proteins is a large hydrophilic loop between helices 6 and 7 at the cytoplasmic side (Baldwin et al., 2004).

The structural determinants for substrate recognition and discrimination by ENT have been recently uncovered based on experiments with recombinant proteins and site-directed mutagenesis. The results of these experiments indicated that the transmembrane region of ENT2 encompassing helices 1-6 is responsible for transport of 3'-deoxynucleosides (Yao et al., 2001), while the TM helices 5-6 of this transporter appear to recognize nucleobases (Yao et al., 2002). Mutation of glycine to serine at position 154 in hENT1 resulted in a loss of its ability to bind NBTI and decreased the affinity for cytidine and adenosine (Hyde et al., 2001; SenGupta \& Unadkat, 2004). Another glycine residue at position 184 in hENT1 was shown to be important for targeting of the transporter to the plasma membrane or/and for the correct folding (SenGupta et al., 2002).

Work on chimeric rat and human ENT proteins indicated that TM domains 3-6 contain residues responsible for the sensitivity to coronary vasodilators and to NBTI (Sundaram et al., 1998; 2001b). The amino acid at position 33 in hENT1 (Met) and hENT2 (Ile) was shown to be responsible for the sensitivity of these transporters to coronary vasodilators such as dilazep, draflazine, and dipyridamole (Visser et al., 2002).

The topological model of hCNT proteins consists of $13 \mathrm{TM}$ helices with the $\mathrm{N}$-terminal region located at the cytoplasmic side (Wang \& Giacomini, 1997; Ritzel et al., 1998; Hamilton et al., 2001). In hCNT the C-terminal hydrophilic part positioned in the extracellular space is glycosylated (Fig. 2) (Hamilton et al., 2001). Experiments on chimeras constructed from rat CNT1 and CNT2 proteins indicated that region encompassing TM 7 
and 9 is responsible for substrate selectivity (Wang \& Giacomini, 1997; Hamilton et al., 2001). Those studies showed that replacing four residues $\left(\mathrm{Ser}^{319}, \mathrm{Gln}^{320}\right.$, Ser ${ }^{353}$, Leu $^{354}$ ) in the TM 7-9 region of hCNT1 to the corresponding residues in hCNT2 $\left(\mathrm{Gly}^{313}\right.$, $\mathrm{Met}^{314}$, $\mathrm{Thr}^{347}, \mathrm{Val}^{348}$ ) resulted in a change of the substrate specificity of the transporter from the cit (pyrimidine specific) to the cif (purine specific) type. Further work indicated that even a single mutation of any of these residues changed the transporter specificity and/or affinity (Loewen et al., 1999). Mutation of serine 319 to glycine in TM7 of hCNT1 produced a transporter able to transport both purines and pyrimidines (cib type), whereas additional mutation of glutamine 320 to methionine increased the activity of the transporter (Loewen et al., 1999). Mutational studies performed on rat CNT1 yielded similar results (Wang \& Giacomini, 1999). Those studies indicate that serine $319 / 318$ (human/rat) is responsible for pyrimidine selectivity of CNT1, whereas the adjacent glutamine (320 and 319 in human and rat, respectively) is important for the modulation of the apparent affinity for nucleosides.

\section{REGULATION OF NUCLEOSIDE TRANSPORTERS}

Our understanding of the mechanisms that regulate the nucleoside transporters is relatively weak comparing to knowledge on their structure and kinetics. Data gathered so far indicate that the expression level of nucleoside transporters depends on the kind of tissue and its physiological state. Down-regulation and recycling is a relatively well-described phenomenon among the regulatory mechanisms of nucleoside transporters. A study performed on adrenal chromaffin cells, a cellular model with a high similarity to neuronal cells, showed that NBTI binding caused quick internalization of the transporter protein. As a result, $50-60 \%$ of the transporter protein was destroyed, but the remaining $40-50 \%$ returned to the plasma membrane (Torres et al., 1992). Other studies demonstrated the presence of a cytoplasmic pool of nucleoside transporters in mammalian reticulocytes (Blostein \& Grafova, 1987; Liang \& Johnstone, 1992).

A study performed on starved rats has demonstrated that food supply modulates the expression level of CNT1 in rat small intestine. It was showed that nucleotide-deficient diets increased the amount of CNT1 protein in jejunum brush border membranes. On the other hand, nucleotide-supplemented diet increased the CNT1 level in the liver but decreased it in the jejunum. These findings suggest that the supply of nucleotides modulates CNT1 expression in a tissue-specific manner (Lopez-Navarro et al., 1996; Mercader et al., 1996; Patil \& Unadkat, 1997; Valdes et al., 2000).
Hormonal regulation of nucleoside transport activity has been reported in several tissues and cell types. Exposition of cultured chromaffin cells to T3 resulted in an increase in the number of nucleoside transporters and stimulation of adenosine transport (Fideu \& Miras-Portugal, 1992). In thyroidectomized rats the NBTI-sensitive adenosine transport was shown to be reduced by $45 \%$ in brain stem synaptosomal preparations (Fideu et al., 1994). A study on rat liver documented up-regulation of nucleoside transport by glucagon through a mechanism involving membrane hyperpolarization (Gomez-Angelats et al., 1996). Insulin was also able to stimulate $\mathrm{Na}^{+}$-dependent uridine uptake by a process consistent with de novo synthesis of the carrier protein (Gomez-Angelats et al., 1996; PastorAnglada et al., 1998). The important role of insulin in the regulation of nucleoside transporters supports the multiple observations from experimental and human diabetes. Decreased nucleoside uptake was reported in hippocampal slices from diabetic rats (Morrison et al., 1992; Cassar et al., 1998). It was also reported that the NBTI-sensitive adenosine transport is reduced in endothelial cells isolated from human diabetic umbilical vein (Sobrevia et al., 1994; Vasquez et al., 2004). On the other hand, in human cells isolated from diabetic umbilical artery smooth muscle adenosine transport was significantly raised (Aguayo et al., 2001). A study performed on rats showed that the mRNA levels of rENT1, rENT2, rCNT1, and CNT2 were significantly altered in diabetic heart, liver, and kidney (Pawelczyk et al., 2003). Experiments performed on cultured rat $\mathrm{T}$ and $\mathrm{B}$ lymphocytes demonstrated that nucleoside transporters expression levels were independently and differentially regulated by glucose and insulin (Sakowicz et al., 2004; 2005). It appears that in rat lymphocytes the expression level of rENT2 and rCNT2 highly depends on insulin but is not affected by changes in extracellular glucose level, whereas the expression level of rENT1 is sensitive to extracellular glucose level but not to insulin. Experiments conducted on rat B lymphocytes have showed that insulin utilizes different signalling pathways to regulate expression of CNT2 and ENT2 transporters (Sakowicz et al., 2005). It was demonstrated that insulin up-regulated the level of ENT2 by signalling through PI3K with no involvement of MAK kinases. On the other hand, insulininduced suppression of CNT2 expression was totally blocked by an inhibitor of MEK-1 (PD98059), indicating that insulin controls CNT2 level by signalling through the MAPK pathway. An elevated level of glucose suppressed expression of ENT1 transporter in rat B lymphocytes by signalling through the MAP kinase pathway (Sakowicz et al., 2005). The ability of elevated glucose to regulate nucleoside transporters by signalling through the MAPK pathway was also reported for human umbilical vein endothelial cells 
and human aortic smooth muscle cells (Montecinos et al., 2000; Leung et al., 2001). In cultured human aortic smooth muscle cells, an increase of extracellular glucose concentration induced expression of ENT1 (Leung et al., 2001; 2005). On the other hand, in human umbilical vein endothelium (HUVEC) the expression level of ENT1 and its transport activity were shown to be reduced by elevated level of glucose (Aguayo et al., 2005). In HUVEC, elevated glucose level affected adenosine transport by a mechanism that involved endothelial NO synthase, PKC and MAP kinases (Montecinos et al., 2000; Aguayo et al., 2005). An involvement of $P_{2 Y 2}$ purinoceptors in the effect of elevated glucose on the NBTI-sensitive adenosine transport in HUVEC was also reported (Parodi et al., 2002). A modulatory role of ATP on the NBTI-sensitive nucleoside transporter in bovine chromaffin cells was also described (Casillas et al., 1993; Delicado et al., 1994).

The data gathered so far indicate that the functioning of nucleoside transporters depends also on cell cycle progression and cell differentiation. Studies performed on LA-N-2 human neuroblastoma cells documented an increased expression of NBTI-insensitive equilibrative nucleoside transporter and enhanced uptake of formycin B during cell differentiation (Jones et al., 1994). Studies conducted on hepatocytes have indicated that hepatocarcinogenesis leads to a selective loss of the concentrative nucleoside transporter CNT2 and an increased expression of nucleoside transporter ENT2 (Plagemann \& Wohlhueter, 1985; del Santo et al., 1998; Dragan et al., 2000; Pastor-Anglada et al., 2001). On the other hand, synchronized hepatoma cell line FAO that had been induced to proliferate displayed an increase in ENT2, CNT1 and CNT2 mRNA levels just before the peak of thymidine incorporation into DNA. In those cells the mRNA level of ENT1 did not change during proliferation. This suggests that ENT2, CNT1 and CNT2 expression appears to be cell cycle-dependent, but ENT1 is constitutively expressed (del Santo et al., 1998; Valdes et al., 2002). It has been demonstrated that in rat during liver regeneration after partial hepatectomy, the activity of sodium-dependent transporters increase concurrently with elevated mRNA and protein levels of CNT1 and CNT2 (Ruiz-Montasell et al., 1993; Felipe et al., 1997; Pastor-Anglada et al., 1998; del Santo et al., 1998). An involvement of growth factors in the regulation of expression of nucleoside transporters was demonstrated in murine bone marrow-derived macrophages. These cells express both the equilibrative (ENT1, ENT2) and concentrative (CNT1, CNT2) nucleoside transporters. A study with the use of isoform-specific probes and antibodies showed that M-CSF-induction of cultured macrophages to proliferate specifically up-regulated only ENT1 at both the mRNA and protein levels. In contrast, exposure of these cells to INF- $\gamma$ increased the expression of CNT1 and CNT2 by a STAT1-independent pathway. INF- $\gamma$ also down-regulated the M-CSF-induced expression of ENT1 (Soler et al., 2001a; 2003). Exposition of rat foetal hepatocytes to growth hormones such as dexamethasone or T3 induced selective upregulation of CNT2 protein and mRNA level and suppressed ENT1 and ENT2 expression (del Santo et al., 2001). Studies performed on human B cell lines have shown that differentiation factors such as phorbol esters (PMA) and LPS up-regulate concentrative transport systems, but down-regulate the equilibrative transporters in a PKC-dependent manner (Soler et al., 1998). PMA and LPS induce also expression of TNF- $\alpha$, but TNF- $\alpha$ alone alters the expression level of equilibrative nucleoside transporters in a PKC-independent manner. On the other hand, it has been demonstrated that activation of concentrative transporters by TNF- $\alpha$ is a process dependent on PKC (Soler et al., 1998; 2001b). Another player involved in PMA-induced alteration of nucleoside transporters is $\mathrm{NO}$, which is required in the regulation of the concentrative transporters but not of the equilibrative ones (Soler et al., 2000).

\section{CONCLUSIONS}

Over the past two decades important advances in the understanding of nucleoside transporter functioning have been achieved. Identification and molecular cloning of the ENT and CNT families from mammals and protozoan parasites have provided detailed information about the structure, function, regulation, and tissue and cellular localization. Structure-function analyses of various nucleoside transporter chimeras and mutants revealed important elements involved in substrate and inhibitor recognition and binding. However, the mechanisms that regulate nucleoside transporters in various tissues and cell types are just beginning to be understood. Because of the ability of these transporters to handle nucleoside analogues used in treatment of patients with cancer and viral diseases, the ongoing research allow the designing of more specifically targeted new compounds or improving the existing drugs. New nucleoside-based drugs are welcome not only in the treatment of cancer and viral diseases, but also in cardiovascular disorders and parasitic infections.

\section{REFERENCES}

Ackley MA, Governo RJM, Cass CE, Young JD, Baldwin SA, King AE (2003) Control of glutamatergic neurotransmission in the rat spinal dorsal horn by the nucleoside transporter ENT1. J Physiol 548: 507-517. 
Aguayo C, Flores C, Parodi J, Rjas R, Mann GE, Pearson JD, Sobrevia L (2001) Modulation of adenosine transport by insulin in human umbilical artery smooth muscle cells from normal or gestational diabetic pregnancies. J Physiol 534: 243-254.

Aguayo C, Casado J, González M, Pearson JD, San Martín R, Casanello P, Pastor-Anglada M, Sobrevia L (2005) Equilibrative nucleoside transporter 2 is expressed in human umbilical vein endothelium, but is not involved in the inhibition of adenosine transport induced by hyperglycaemia. Placenta 26: 641-653.

Anderson CM, Xiong W, Young JD, Cass CE, Parkinson FE (1996) Demonstration of the existence of mRNAs encoding N1/cif and N2/cit sodium/nucleoside cotransporters in rat brain. Brain Res Mol Brain Res 42: 358361.

Badagnani I, Chan W, Castro RA, Brett CM, Huang CC, Stryke D, Kawamoto M, Johns SJ, Ferrin TE, Carlson EJ, Burchard EG, Giacomini KM (2005) Functional analysis of genetic variants in the human concentrative nucleoside transporters 3 (CNT3; SLC28A3). Pharmacogenomics J 5: 157-165.

Baldwin SA, Mackey JR, Cass CE, Young JD (1999) Nucleoside transporters: molecular biology and implications for therapeutic development. Mol Med Today 5: 216-224.

Baldwin SA, Beal PR, Yao SY King AE, Cass CE, Young JD (2004) The equilibrative nucleoside transporter family, SLC29. Pflugers Arch Eur J Physiol 447: 735-743.

Baldwin SA, Yao SY, Hyde RJ, Ng AM, Foppolo S, Barnes K, Ritzel MW, Cass CE, Young JD (2005) Functional characterization of novel human and mouse equilibrative nucleoside transporters (hENT3 and mENT3) located in intracellular membranes. I Biol Chem 280: 15880-15887.

Blostein R, Grafova E (1987) Characteristics of membrane transport losses during reticulocyte maturation. Biochem Cell Biol 65: 869-875.

Cabrita M, Baldwin S, Young J, Cass C (2002) Molecular biology and regulation of nucleoside and nucleobase transporter proteins in eukaryotes and prokaryotes. Biochem Cell Biol 80: 632-638.

Casillas T, Delicado EG, Miras-Portugal MT (1993) Adenosine 5 '-triphosphate modulation of nitrobenzylthioinosine binding sites in plasma membranes of bovine chromaffin cells. Neurosci Lett 164: 51-54.

Cass CE, Young JD, Baldwin SA (1998) Recent advances in the molecular biology of nucleoside transporters of mammalian cells. Biochem Cell Biol 76: 761-770.

Cassar M, Jones MG, Szatkowski M (1998) Reduced adenosine uptake accelerates ischaemic block of population spikes in hippocampal slices from streptozotocintreated diabetic rats. Eur J Neurosci 10: 239-245.

Che M, Ortiz DF, Arias IM (1995) Primary structure and functional expression of a cDNA encoding the bile canicular, purine-specific $\mathrm{Na}^{+}$-nucleoside cotransporter. $J$ Biol Chem 270: 13596-13599.

Crawford CR, Patel DH, Naeves C, Belt JA (1998) Cloning of the human equilibrative nitrobenzylmercaptopurine riboside (NBMPR)-insensitive nucleoside transporter $e i$ by functional expression in a transport-deficient cell line. J Biol Chem 273: $5288-5293$.

Delicado EG, Casillas T, Sen RP, Miras-Portugal MT (1994) Evidence that adenine nucleotides modulate nucleoside-transporter function. Characterization of uridine transport in chromaffin cells and plasma membrane vesicles. Eur J Biochem 225: 355-362.

del Santo B, Valdes R, Mata JM, Felipe A, Casado FJ, Pittot H, Pastor-Anglada M (1998) Differential expression and regulation of nucleoside transport systems in rat liver parenchymal and hepatoma cells. Hepatology 28: 1504-1511.

del Santo B, Tarafa G, Felipe A, Casado FJ, Pastor-Anglada M (2001) Developmental regulation of the concentrative nucleoside transporters CNT1 and CNT2 in rat liver. I Hepatol 34: 873-880.

Dragan Y, Valdes R, Gomez-Angelats M, Felipe A, Casado FJ, Pitot H, Pastor-Anglada M (2000) Selective loss of nucleoside carrier expression in rat hepatocarcinomas. Hepatology 32: 239-246.

Dunwiddie TV, Masino SA (2001) The role and regulation of adenosine in the central nervous system. Annu Rev Neurosci 24: 31-55.

Felipe A, Ferrer-Martinez A, Casado FJ, Pastor-Anglada M (1997) Expression of sodium-dependent purine nucleoside carrier (SPNT) mRNA correlates with nucleoside transport activity in rat liver. Biochem Biophys Res Commun 233: 572-575.

Fideu MD, Miras-Portugal MT (1992) Long term regulation of nucleoside transport by thyroid hormone (T3) in cultured chromaffin cells. Neurochem Res 17: 1099-1104.

Fideu MD, Arce A, Esquifino AI, Miras-Portugal MT (1994) Thyroid hormones modulate both adenosine transport and adenosine A1 receptors in rat brain. Am J Physiol Cell Physiol 267: C1651-C1656.

Flanagan SA, Meckling-Gill GA (1997) Characterization of a novel $\mathrm{Na}^{+}$-dependent, guanosine specific, nitrobenzylthioinosine-sensitive transporter in acute promyelocytic leukemia cells. J Biol Chem 272: 18026-18032.

Gray J, Owen R, Giacomini K (2004) The concentrative nucleoside transporter family, SLC28. Pflugers Arch Eur J Physiol 447: 728-734.

Gerstin KM, Dresser MJ, Giacomini KM (2002) Specificity of human and rat orthologs of the concentrative nucleoside transporter, SPNT. Am I Physiol 283: F344-F349.

Gomez-Angelats M, del Santo B, Mercader J, Ferrer-Martinez A, Felipe A, Casado J, Pastor-Anglada M (1996) Hormonal regulation of concentrative nucleoside transport in liver parenchymal cells. Biochem J 313: 915-920.

Griffith DA, Jarvis SM (1996) Nucleoside and nucleobase transport systems of mammalian cells. Biochim Biophys Acta 1286: 153-181.

Griffiths M, Yao SY, Abidi F, Phillips SE, Cass CE, Young JD, Baldwin SA (1997) Molecular cloning and characterization of a nitrobenzylthioinosine-insensitive (ei) equilibrative nucleoside transporter from human placenta. Biochem J 328: 739-743.

Hamilton SR, Yao SY, Ingram JC, Hadden DA, Ritzel MW, Gallagher MP, Henderson PJ, Cass CE, Young JD, Baldwin SA (2001) Subcellular distribution and membrane topology of the mammalian concentrative $\mathrm{Na}^{+}$-nucleoside cotransport rCNT. I Biol Chem 276: 27981-27988.

Handa M, Choi D, Caldeiro RM, Messing RO, Gordon AS, Diamond I (2001) Cloning of a novel isoform of the mouse NBMPR-sensitive equilibrative nucleoside transporter (ENT1) lacking a putative phosphorylation site. Gene 262: 301-307.

Hogue DL, Hodgson KC, Cass CE (1990) Effects of inhibition of $\mathrm{N}$-linked glycosylation by tunicamycin on nucleoside transport polypeptides of L1210 leukemia cells. Biochem Cell Biol 68: 199-209.

Huang Q-Q, Harvey CM, Paterson AR, Cass CE, Young JD (1993) Functional expression of $\mathrm{Na}(+)$-dependent nucleoside transport systems of rat intestine in isolated oocytes of Xenopus leavis. Demonstration that rat jejunum expresses the purine-selective system N1 (cif) and a second, novel system N3 having broad specificity for purine and pyrimidine nucleosides. J Biol Chem 268: 20613-20619. 
Huang Q-Q, Yao SY, Ritzel MW, Paterson AR, Cass CE, Young JD (1994) Cloning and functional expression of a complementary DNA encoding a mammalian nucleoside transport protein. J Biol Chem 269: 17757-17760.

Hyde RJ, Cass CE, Young JD, Baldwin SA (2001) The ENT family of eukaryote nucleoside and nucleobase transporters: recent advances in the investigation of structure/function relationships and the identification of novel isoforms. Mol Memb Biol 18: 53-63.

Jones KW, Rylett RJ, Hammond JR (1994) Effect of cellular differentiation on nucleoside transport in human neuroblastoma cells. Brain Res 660: 104-112.

Kiss A, Farah K, Kim J, Garriocki R, Drysdale T, Hammond J (2000) Molecular cloning and functional characterization of inhibitor-sensitive (mENT1) and inhibitorresistant (mENT2) equilibrative nucleoside transporters from mouse brain. Biochem I 352: 363-372.

Kong W, Engel K, Wang J (2004) Mammalian nucleoside transporters. Curr Drug Metab 5: 63-84.

Liang L, Johnstone RM (1992) Evidence for an internal pool of nucleoside transports in mammalian reticulocytes. Biochim Biophys Acta 1106: 189-196.

Leung G, Ward J, Wong P, Tse C (2001) Characterization of nucleoside transport systems in cultured rat epididymal epithelium. Am J Cell Physiol 280: C1076-C1082.

Leung GPH, Man RYK, Tse C (2005) D-Glucose transport upregulates adenosine transport in cultured human aortic smooth muscle cells. Am I Physiol Heart Circ Physiol 288: H2756-H2762.

Loewen SK, Ng AM, Yao SY, Cass CE, Baldwin SA, Young JD (1999) Identification of amino acid residues responsible for the pyrimidine and purine nucleoside specificities of human concentrative $\mathrm{Na}^{+}$nucleoside cotransports hCNT1 and hCNT2. I Biol Chem 274: 24475-24484

Lopez-Navarro AT, Ortega MA, Peragon J, Bueno JD, Gil A, Sanchez-Pozo A (1996) Deprivation of dietary nucleotides decreases protein synthesis in the liver and small intestine in rats. Gastroenterology 110: 1760-1769.

Lum P, Ngo L, Bakken A, Unadkat J (2000) Human intestinal es nucleoside transporter: molecular characterization and nucleoside inhibitory profiles. Cancer Chemother Pharmacol 45: 273-278.

Mackey JR, Baldwin SA, Young JD, Cass CE (1998) Nucleoside transport and its significance for anticancer drug resistance. Drug Resist Updat 1: 310-324.

Mercader J, Gomez-Angelats M, del Santo B, Casado FJ, Felipe A, Pastor-Anglada M (1996) Nucleoside uptake in rat liver parenchymal cells. Biochem J 317: 835-842.

Montecinos VP, Aguayo C, Flores C, Wyatt AW, Pearson JD, Mann GE, Sobrevia L (2000) Regulation of adenosine transport by D-glucose in human fetal endothelial cells: involvement of nitric oxide, protein kinase $\mathrm{C}$ and mitogen-activated protein kinase. J Physiol 529: 777-790.

Morrison PD, Mackinnon MWB, Bartrup JT, Skett PG, Stone TW (1992) Changes in adenosine sensitivity in the hippocampus of rats with streptozotocin-induced diabetes. Br I Pharmacol 105: 1004-1008.

Mubagwa K, Flameng W (2001) Adenosine, adenosine receptors and myocardial protection: an updated overview. Cardiovasc Res 52: 25-39.

Olah ME, Stiles GL (2000) The role of receptor structure in determining adenosine receptor activity. Pharmacol Ther 85: 55-75.

Parodi J, Flores C, Aguayo C, Rudolph MI, Casanello P, Sobrevia L (2002) Inhibition of nitrobenzylthioinosinesensitive adenosine transport by elevated D-glucose involves activation of $\mathrm{P}_{2 Y_{2}}$ purinoceptors in human umbilical vein endothelial cells. Cir Res 90: 570-577.
Pastor-Anglada M, Felipe A, Casado F, Santo B, Mata J, Valdes R (1998) Nucleoside transporters and liver cell growth. Biochem Cell Biol 76: 771-777.

Pastor-Anglada M, Casado J, Valdes R, Mata J, GarciaManteiga J, Molina M (2001) Complex regulation of nucleoside transporter expression in epithelial and immune system cells. Mol Memb Biol 18: 81-85.

Pastor-Anglada M, Cano-Soldado P, Molina-Arcas M, Lostao MP, Larrayoz I, Martinez-Picado J, Casado FJ (2005) Cell entry and export of nucleoside analogues. Virus Res 107: 151-164.

Patil SD, Unadkat JD (1997) Sodium dependent nucleoside transport in the human intestinal brush border membrane. Am J Physiol 35: G1314-G1320.

Patil SD, Ngo LY, Glue P, Unadkat JD (1998) Intestinal absorption of ribavirin is preferentially mediated by the $\mathrm{Na}^{+}$-nucleoside purine (N1) transporter. Pharm Res 15: 950-952.

Pawelczyk T, Podgorska M, Sakowicz M (2003) The effect of insulin on expression level of nucleoside transporters in diabetic rats. Mol Pharmacol 63: 81-88.

Pennycooke M, Chaudary N, Shuralyova I, Zhang Y, Coe $R$ (2001) Differential expression of human nucleoside transporters in normal and tumor tissue. Biochem Biophys Res Commun 280: 951-959.

Plagemann PG, Wohlhueter RM (1985) Nitrobenzylthioinosine-sensitive and -resistant nucleoside transport in normal and transformed rat cells. Biochim Biophys Acta 816: 387-395.

Plagemann PG, Aran JM (1990) Characterization of $\mathrm{Na}^{+}$-dependent, active nucleoside transport in rat and mouse peritoneal macrophages, a mouse macrophage cell line and normal rat kidney cells. Biochim Biophys Acta 1028: 289-298.

Ritzel MW, Yao SY, Huang MY, Elliott JF, Cass CE, Young JD (1997) Molecular cloning and functional expression of cDNAs encoding a human $\mathrm{Na}^{+}$-nucleoside cotransporter (hCNT1). Am J Physiol 272: C707-C714.

Ritzel MW, Yao SY, Ng AM, Mackey JR, Cass CE, Young JD (1998) Molecular cloning, functional expression and chromosomal localization of a cDNA encoding a human $\mathrm{Na}^{+} /$nucleoside cotransporter (hCNT2) selective for purine nucleosides and uridine. Mol Membr Biol 15: 203-211.

Ritzel MW, Ng AM, Yao SY, Graham K, Loewen SK, Smith KM, Ritzel RG, Mowles DA, Carpenter P, Chen X-Z, Karpinski E, Hyde RJ, Baldwin SA, Cass CE, Young JD (2001) Molecular identification and characterization of novel human and mouse concentrative $\mathrm{Na}^{+}$-nucleoside cotransporter proteins (hCNT3 and mCNT3) broadly selective for purine and pyrimidine nucleosides (system cib). J Biol Chem 276: 2914-2927.

Rosales OR, Eades B, Assali AR (2004) Cardiovascular drugs: adenosine role in coronary syndromes and percutaneous coronary interventions. Catheter Cardiovasc Interv 62: 358-363.

Ruiz-Montasell B, Martinez-Mass JV, Enrich C, Casado FJ, Felipe A, Pastor-Anglada M (1993) Early induction of $\mathrm{Na}(+)$-dependent uridine uptake in the regenerating rat liver. FEBS Lett 316: 85-88.

Sakowicz M, Szutowicz A, Pawelczyk T (2004) Insulin and glucose induced changes in expression level of nucleoside transporters and adenosine transport in rat $\mathrm{T}$ lymphocytes. Biochem Pharmacol 68: 1309-1320.

Sakowicz M, Szutowicz A, Pawelczyk T (2005) Differential effect of insulin and elevated glucose level on adenosine transport in rat B lymphocytes. Int Immunol 17: 145-154.

SenGupta DJ, Unadkat JD (2004) Glycine 154 of the equilibrative nucleoside transporter, hENT1, is important 
for nucleoside transport and for conferring sensitivity to the inhibitors nitrobenzylthioinosine, dipyridamole, and dilazep. Biochem Pharmacol 67: 453-458.

SenGupta DJ, Lum PY, Lai Y, Shubochkina E, Bakken AH, Schneider G, Unadkat JD (2002) A single glycine mutation in the equilibrative nucleoside transporter gene, hENT1, alters nucleoside transport activity and sensitivity to nitrobenzylthioinosine. Biochemistry 41: 15121519.

Sobrevia L, Jarvis SM, Yudilevich DL (1994) Adenosine transport in cultured human umbilical vein endothelial cells is reduced in diabetes. Am J Physiol 267: C39-C47.

Soler C, Felipe A, Mata JF, Casado J, Celada A, PastorAnglada M (1998) Regulation of nucleoside transport by lipopolysaccharide, phorbol esters and tumor necrosis factor- $\alpha$ in human B-lymphocytes. J Biol Chem 273: 26939-26945.

Soler C, Felipe A, Casado FJ, Celada A, Pastor-Anglada M (2000) Nitric oxide regulates nucleoside transport in activated B lymphocytes. J Leukocyte Biol 67: 345-349.

Soler C, Garcia-Manteiga J, Valdes R, Xaus J, Comalada M, Casado FJ, Pastor-Anglada M, Celada A, Felipe A (2001a) Macrophages require different nucleoside transport systems for proliferation and activation. FASEB 15: 1979-1988

Soler C, Valdes R, Garcia-Manteiga I, Xaus J, Comalada M, Casado FJ, Modolell M, Nicholson B, MacLeod C, Felipe A, Celada A, Pastor-Anglada M (2001b) Lipopolysaccharide-induced apoptosis of macrophages determines the up-regulation of concentrative nucleoside transporters Cnt1 and Cnt2 through tumor necrosis factor- $\alpha$-dependent and -independent mechanisms. J Biol Chem 276: 30043-30049.

Soler C, Felipe A, Garcia-Manteiga J, Serra M, GuuillenGomez E, Casado FJ, MacLeod C, Modolell M, Pastor-Anglada M, Celada A (2003) Interferon- $\gamma$ regulates nucleoside transport systems in macrophages through signal transduction and activator of transduction factor 1 (STAT1)-dependent and independent signalling pathways. Biochem J 375: 777-783.

Sundaram M, Yao SY, Ng AM, Griffiths M, Cass CE, Baldwin SA, Young JD (1998) Chimaeric constructs between human and rat equilibrative nucleoside transporters (hENT1 and rENT1) reveal hENT1 structural domains interacting with coronary vasoactive drugs. J Biol Chem 273: 21519-21525.

Sundaram M, Yao SY, Ingram JC, Berry ZA, Abidi F, Cass CE, Baldwin SA, Young JD (2001a) Topology of a human equilibrative, nitrobenzylthioinosine (NBMPR)sensitive nucleoside transporter (hENT1) implicated in cellular uptake of adenosine and anti-cancer drugs. J Biol Chem 276: 45270-45275.

Sundaram M, Yao SY, Ng AM, Cass CE, Baldwin SA, Young JD (2001b) Equilibrative nucleoside transporters: mapping regions of interaction for the substrate analogue nitrobenzylthioinosine (NBMPR) using rat chimeric proteins. Biochemistry 40: 8146-8151.

Torres M, Delicado EG, Fideu MD, Miras-Portugal MT (1992) Down-regulation and recycling of the nitrobenzylthioinosine-sensitive nucleoside transporter in cultured chromaffin cells. Biochim Biophys Acta 1105: 291299.

Thorn J, Jarvis S (1996) Adenosine transporters. Gen Pharmac 27: 613-620.

Valdes R, Ortega MA, Casado J, Felipe A, Gil A, SanchezPozo A, Pastor-Anglada M (2000) Nutrional regulation of nucleoside transporter expression in rat small intestine. Gastroenterology 119: 1623-1630.
Valdes R, Casado FJ, Pastor-Anglada M (2002) Cell-cycledependent regulation of CNT1, a concentrative nucleoside transporter involved in the uptake of cell-cycle dependent nucleoside-derived anticancer drugs. Biochem Biophys Res Commun 296: 575-579.

Vasquez G, Sanhueza F, Vasquez R, Gonzalez M, San Martin R, Casanello P, Sobrevia L (2004) Role of adenosine transport in gestational diabetes-induced L-arginine transport and nitric oxide synthesis in human umbilical vein endothelium. J Physiol 560: 111-122.

Vickers MF, Mani RS, Sundaram M, Hogue DL, Young JD, Baldwin SA, Cass CE (1999) Functional production and reconstitution of the human equilibrative nucleoside transporter (hENT1) in Saccharomyces cerevisiae - interaction of inhibitors of nucleoside transport with recombinant hENT1 and a glycosylation-defective derivative (hENT1/N48Q). Biochem J 339: 21-32.

Visser F, Vickers MF, Ng AM, Baldwin SA, Young JD, Cass CE (2002) Mutation of residue 33 of human equilibrative nucleoside transporters 1 and 2 alters sensitivity to inhibition of transport by dilazep and dipyridamole. $J$ Biol Chem 277: 395-401.

Wang J, Giacomini KM (1997) Molecular determinants of substrate selectivity in $\mathrm{Na}^{+}$-dependent nucleoside transporters. J Biol Chem 272: 28845-28848.

Wang J, Giacomini KM (1999) Serine 318 is essential for the pyrimidine selectivity of the $\mathrm{N} 2 \mathrm{Na}^{+}$-nucleoside transporter. J Biol Chem 274: 2298-2302.

Wang J, Su SF, Dresser MJ, Schaner ME, Washington CB, Giacomini KM (1997) $\mathrm{Na}^{+}$-dependent purine nucleoside transporter from human kidney: cloning and functional characterization. Am I Physiol 273: F1058-F1065.

Ward J, Sherali A, Mo Z, Tse C (2000) Kinetic and pharmacological properties of cloned human equilibrative nucleoside transporters, ENT1 and ENT2, stably expressed in nucleoside transporter-deficient PK15 cells. J Biol Chem 275: 8375-8381.

Ward JL, Leung GP, Toan SV, Tse CM (2003) Functional analysis of site directed glycosylation mutants of the human equilibrative nucleoside transporter-2. Arch Biochem Biophys 411: 19-26.

Yao SY, Ng AM, Muzyka WR, Griffiths M, Cass CE, Baldwin SA, Young JD (1997) Molecular cloning and functional characterization of nitrobenzylthioinosine (NBMPR)-sensitive (es) and NBMPR-insensitive (ei) equilibrative nucleoside transporter proteins (rENT1 and rENT2) from rat tissues. J Biol Chem 272: 28423-28430.

Yao SY, Ng AM, Sundaram M, Cass CE, Baldwin SA, Young JD (2001) Transport of antiviral 3'-deoxynucleoside drugs by recombinant human and rat equilibrative, nitrobenzylthioinosine (NBMPR)-insensitive (ENT2) nucleoside transporter proteins produced in Xenopus oocytes. Mol Membr Biol 18: 161-167.

Yao SY, Ng AM, Vickers MF, Sundaram M, Cass CE, Baldwin SA, Young JD (2002) Functional and molecular characterization of nucleobase transport by recombinant human and rat equilibrative nucleoside transporters 1 and 2. Chimeric constructs reveal a role for the ENT2 helix 5-6 region in nucleobase. I Biol Chem 277: 24938-24948.

Zhang J, Visser F, Vickers MF, Lang T, Robins MJ, Nielsen LPC, Nowak I, Baldwin SA, Young JD, Cass CE (2003) Uridine binding motifs of human concentrative nucleoside transporters 1 and 3 produced in Saccharomyces cerevisiae. Mol Pharmacol 64: 1512-1520. 